\title{
Do new ways of working increase informal learning?
}

Citation for published version (APA):

Gerards, R., de Grip, A., \& Weustink, A. (2018). Do new ways of working increase informal learning? ROA. ROA Research Memoranda No. 001 https://doi.org/10.26481/umaror.2018001

Document status and date:

Published: 01/01/2018

DOI:

10.26481/umaror.2018001

Document Version:

Publisher's PDF, also known as Version of record

\section{Please check the document version of this publication:}

- A submitted manuscript is the version of the article upon submission and before peer-review. There can be important differences between the submitted version and the official published version of record.

People interested in the research are advised to contact the author for the final version of the publication, or visit the DOI to the publisher's website.

- The final author version and the galley proof are versions of the publication after peer review.

- The final published version features the final layout of the paper including the volume, issue and page numbers.

Link to publication

\footnotetext{
General rights rights.

- You may freely distribute the URL identifying the publication in the public portal. please follow below link for the End User Agreement:

www.umlib.nl/taverne-license

Take down policy

If you believe that this document breaches copyright please contact us at:

repository@maastrichtuniversity.nl

providing details and we will investigate your claim.
}

Copyright and moral rights for the publications made accessible in the public portal are retained by the authors and/or other copyright owners and it is a condition of accessing publications that users recognise and abide by the legal requirements associated with these

- Users may download and print one copy of any publication from the public portal for the purpose of private study or research.

- You may not further distribute the material or use it for any profit-making activity or commercial gain

If the publication is distributed under the terms of Article $25 \mathrm{fa}$ of the Dutch Copyright Act, indicated by the "Taverne" license above, 


\section{Maastricht University $\mathrm{ROA}$}

\section{Do new ways of working increase informal learning?}

Ruud Gerards

Andries de Grip

Arnoud Weustink

\section{ROA Research Memorandum}

ROA-RM-2018/1

Researchcentrum voor Onderwijs en Arbeidsmarkt | ROA Research Centre for Education and the Labour Market / ROA 


\title{
Do new ways of working increase informal learning?
}

\author{
Ruud Gerards \\ Andries de Grip \\ Arnoud Weustink
}

ROA-RM-2018/1*

April 2018

Research Centre for Education and the Labour Market

Maastricht University

P.O. Box 616, 6200 MD Maastricht, The Netherlands

$\mathrm{T}+31433883647 \mathrm{~F}+31433884914$

secretary-roa-sbe@maastrichtuniversity.nl

www.roa.nl

\footnotetext{
* The ROA Research Memorandum Series was created in order to make research results available for discussion, before those results are submitted for publication in journals.
} 


\section{Abstract}

\section{Do new ways of working increase informal learning?**}

This paper is the first study on the impact of new ways of working (NWW) on informal earning at work. Controlling for a wide range of known antecedents of informal learning, we find that NWW, as an aggregate construct, are positively related to employees' informal learning in the Netherlands. This relation is partially mediated by the frequency with which employees receive feedback from their supervisor and coworkers. This mediating effect mostly runs via critical feedback and less so via positive feedback. However, the direct effect of NWW on informal learning is greater than the total indirect effect. Further analysis shows that one particular NWW facet, access to organizational knowledge, is an independent driver of informal learning that is hardly mediated by receiving feedback. Our findings suggest that human resource and general managers who seek new ways to stimulate informal learning can do so by giving their employees more access to organizational knowledge, for instance, by leveraging the potential of modern information and communication technologies.

Keywords: informal learning, new ways of working, feedback, teleworking, multiple mediation

Ruud Gerards

Maastricht University

ROA

P.O. Box 616

NL-6200 MD Maastricht

The Netherlands

r.gerards@maastrichtuniversity.nl and GSBE

Arnoud Weustink

Maastricht University

School of Business Economics

P.O. Box 616

NL-6200 MD Maastricht

The Netherlands

a.weustink@maastrichtuniversity.nl

\author{
Andries de Grip \\ Maastricht University \\ ROA \\ P.O. Box 616 \\ NL-6200 MD Maastricht \\ The Netherlands \\ a.degrip@maastrichtuniversity.nl \\ and IZA
}

\footnotetext{
** We thank Simon Beausaert and Sanne van Wetten for their valuable comments and suggestions, and Evert Webers of RMI for facilitating the fieldwork. We also thank participants of the James Cook University College of Business, Law and Governance seminar for their comments.
} 


\section{Introduction}

Fueled by ongoing globalization and advances in information and communication technologies, the current knowledge-based economy demands the continuous adaptation of management and organization practices for organizations to remain competitive in their sales markets, as well as in the labor market. This has led to much scholarly interest in the accompanying changes in human resource management practices (Laursen and Foss, 2003), in informal learning in the workplace as a key instrument in keeping workers' skills up-to-date with changes in job content (De Grip, 2015; Noe et al., 2013), and in changes in the organization of work that build on the opportunities created by information and communication technologies, such as the proliferation of teleworking due to affordable mobile connections (Allen et al., 2015) and the introduction of more individualized employment relations (e.g., De Leede et al., 2004). Due to the tendency for such new practices to be adopted in bundles (Laursen and Mahnke, 2001), the concept of new ways of working (NWW) has emerged (Peters et al., 2014), which Gerards et al. (2018) define as consisting of five facets: 1) time- and location-independent work, 2) management on output, 3) access to organizational knowledge, 4) flexibility in working relations, and 5) freely accessible open workplaces.

To the best of our knowledge, this paper is the first to explicitly study whether the changes in work organization and human resource management practices bundled into NWW affect informal learning in the workplace. Gerards et al. (2018) note that various facets of NWW increase workers' autonomy in their job, autonomy being a known driver of informal learning (e.g., Van Ruysseveldt and Van Dijke, 2011). This suggests that we might expect NWW to have a positive impact on informal learning. Furthermore, various studies show that informal learning is fostered by the availability of feedback (e.g., Cerasoli et al., 2017; Schürmann and Beausaert, 
2016). Therefore, we investigate the effect of NWW on informal learning, including the frequency of receiving feedback as a mediator.

Our paper connects various fields of research and makes several contributions to them.

First, our research question relates the literature on NWW to the literature on informal learning in the workplace. Specifically, we extend the literature on the antecedents of informal learning with drivers that are related to major developments in many organizations, such as time- and locationindependent work, management on output, access to organizational knowledge, and open workplaces. Second, we extend the emerging literature on the effects of NWW on employee outcomes such as work engagement (Gerards et al., 2018; Ten Brummelhuis et al., 2012), employee performance (De Leede and Kraijenbrink, 2014), work-related flow (Peters et al., 2014), and productivity and organizational commitment (De Leede and Heuver, 2017). Third, we are the first to explicitly link the NWW context to the frequency of receiving feedback. Fourth, in doing so, we also contribute to the literature on the effects of teleworking on workplace outcomes, as well as the literature on the feedback environment (e.g., Steelman et al., 2004), in which the antecedents of the feedback environment have been understudied (Dahling et al., 2017) and the frequency of receiving feedback is a key facet (Steelman et al., 2004).

This paper proceeds as follows. Section 2 discusses the literature on NWW, the drivers of informal learning, and the importance of receiving feedback at work, respectively. From this literature, we derive our empirical model and hypotheses. Section 3 describes our data and variables of interest, followed by Section 4, which presents our estimation results. Section 5 discusses the findings, theoretical contributions, practical implications, and limitations of our paper and recommendations for future research, respectively. 


\section{NWW, receiving feedback, and informal learning}

\section{2. $1 \mathrm{NWW}$}

Several definitions of NWW exist in the literature, disentangling NWW into three to five facets, usually including at least an element of teleworking and management on output (e.g., De Leede and Kraijenbrink, 2014; Peters et al., 2013). We follow Gerards et al. (2018), who build on Baane et al. (2010), Graham (2004), and Halford (2005), and disentangle NWW into five facets: 1) time- and location-independent work, 2) management on output, 3) access to organizational knowledge, 4) flexibility in working relations, and 5) a freely accessible open workplace. We now explain each of these five facets. ${ }^{1}$

The first NWW facet (time- and location-independent work) refers to working independently of time and place (Baane et al., 2010; Halford, 2005), which is related to opportunities for teleworking (Ter Hoeven and Van Zoonen, 2015). The second NWW facet refers to management on output or performance, rather than management of how employees conduct their work (Baane et al., 2010). Management on output allows the workers themselves to determine the way they work (Thompson and Prottas, 2006). The third NWW facet refers to free access to and use of organizational knowledge, experience, and ideas. Current information and communication technologies enable workers to freely access organizational knowledge on their tablets, smartphones, or computers and quickly reach their colleagues and managers (Baane et al., 2010). The fourth NWW facet refers to practices that allow employees to accommodate their working life such that it fits their current private situation and preferences. The fifth facet (open workplace) refers to a physical element of NWW workplaces, that is, refurbishing offices into

1. For more details on the five facets, see Gerards et al. (2018). 
freely accessible open workplaces to minimize physical and mental distance by stimulating encounters and cooperation among colleagues.

\subsection{Informal learning}

The literature on informal learning and workplace learning focuses on 1) "learning by doing,"

2) learning from non-interpersonal sources (such as reading professional or academic literature) and 3) learning from peers and supervisors (e.g., De Grip et al., 2016; Noe et al., 2013; Tews et al., 2017). Several studies show that informal learning accounts for most of the learning in organizations (e.g., Bear et al., 2008; De Grip, 2015). Marsick and Watkins (2001, p. 28) define informal learning as learning that happens "wherever people have the need, motivation and opportunity for learning."

In their meta-study on informal learning behaviors, Cerasoli et al. (2017) group the antecedents of informal learning under the headings of demographics, individual predispositions, and situational antecedents. Most other studies focus on a single group of antecedents of informal learning. For instance, Noe et al. (2013) focus on individual predispositions such as personality traits, whereas others focus on situational antecedents such as the workplace learning culture, access to resources, and peer and supervisor support (e.g., De Grip et al., 2016; Ellinger, 2005; Kyndt et al., 2009; Tews et al., 2017). A common finding across these studies is that learning from peers and supervisors is fostered by receiving feedback (e.g., Cerasoli et al., 2017; Schürmann and Beausaert, 2016).

Although no earlier research explicitly focuses on the relation between NWW and informal learning, a number of studies that investigate NWW in relation to outcome variables closely related to informal learning can help in forming expectations about the effects of NWW on informal learning. In a case study of 73 employees in a Dutch organization, Blok et al. (2012) 
find that NWW reduce knowledge sharing. Furthermore, various studies show the relation between one or more individual facets of NWW and informal learning or related variables. Several studies on teleworking, which can be considered a subset of NWW comprising the first three facets of NWW, report negative effects of teleworking on informal learning (Cooper and Kurland, 2002; Kurland and Bailey, 1999), information exchange frequency (Fonner and Roloff, 2010), and knowledge sharing (Allen et al., 2015). To quote one example: "The private sector managers complained that telecommuters missed out on these learning opportunities because team members often learned from one another informally" (Cooper and Kurland, 2002, p. 521). In contrast, De Leede and Kraijenbrink (2014) find that workers' autonomy with regard to their work schedule and location positively affects trust in colleagues, trust in leaders, and social cohesion, as measured, for example, with informal learning-related items such as feedback and co-workers helping each other. Boell et al. $(2016$, p. 128) focus on the often paradoxical findings in telework research and conclude that the jury is still out on whether telework "is ultimately a 'good' or a 'bad' thing."

Gerards et al. (2018) and Peters et al. (2014) combine insights on the impact of the various facets of NWW with those of the Job Demands-Resources (JD-R) model (Bakker and Demerouti, 2007) to explain the mechanisms affecting, respectively, work engagement and "work-related flow." Similarly, the JD-R model offers the theoretical framework for the effects of NWW on informal learning, emphasizing that job demands can be stressors while job resources can be motivators for informal learning. Peters et al. (2014) argue that NWW practices induce important resources at the job level, as well as at the interpersonal level. All facets of NWW we distinguish increase job resource autonomy (Gerards et al., 2018), which is found to relate positively to informal learning (e.g., Cerasoli et al., 2017; Else Ouweneel et al. 2009; Gijbels et al., 2012; Wielenga-Meijer et al., 2010). Therefore, our first hypothesis is as follows. 


\section{H1: $\quad$ All five facets of NWW are positively related to informal learning.}

Building on Cerasoli et al. (2017), we will test this hypothesis, controlling for a range of known antecedents of informal learning. The demographics we include are age, education level, and job tenure. The individual predispositions we include are the Big Five personality traits-

conscientiousness, neuroticism, openness to experience, agreeableness, and extraversion — as well as optimism, work motivation, and recent formal training participation. The situational antecedents we include are the percentage of time spent performing teamwork, the amount of organizational learning support received, the industry sector, and the occupational field.

\subsection{Frequency of receiving feedback as a mediator}

The importance of feedback for informal learning is well established in the literature (e.g., Eraut, 2004). Theoretically, feedback stimulates reflection (Noe et al., 2013) and needs processing, which both consist of informal learning activities (Mulder, 2013). Moreover, in terms of the JD-R model, feedback is a job resource that is empirically shown to have a positive effect on informal learning (e.g., Cerasoli et al., 2017; Mulder, 2013; Nelen and De Grip, 2009; Schürmann and Beausaert, 2016; Wielenga-Meijer et al., 2010).

For feedback to function as a mediator between NWW and informal learning, NWW should also affect feedback. The literature on feedback is unambiguous about the fact that contextual variables influence feedback (e.g., Anseel et al., 2015; London, 1995; Steelman et al., 2004). Although no studies explicitly link NWW to the frequency of receiving feedback, various studies find that NWW affect variables included in the feedback environment scale (FES; Steelman et al., 2004) and/or the quality of leader-member exchange (LMX; e.g., Gerstner and Day, 1997; Graen and Uhl-Bien, 1995). The feedback environment consists of seven facets: source credibility, feedback quality, feedback delivery, frequency of favorable feedback, 
frequency of unfavorable feedback, source availability, and promoting feedback seeking (Steelman et al., 2004), where the feedback sources are usually supervisors and co-workers. The quality of LMX refers to the quality of the exchange relation between supervisors and subordinates, which is part of the social context of feedback and is significantly positively correlated to the facets of the FES (Steelman et al., 2004).

Peters et al. (2014) argue that NWW practices stimulate important resources at the interpersonal level, such as the supportive behavior of line managers and colleagues, which enhances LMX quality and thus the feedback environment. De Leede and Kraijenbrink (2014), studying a Dutch insurance firm, find that NWW positively affect trust in colleagues, trust in leaders, and social cohesion, which they measured amongst others with items on feedback. The authors also find that NWW relate to, for instance, the source credibility facet of the FES, which depends on the trustworthiness of the feedback sources (Giffin, 1967). Moreover, in a five-day diary study, Ten Brummelhuis et al. (2012) find that NWW positively affect effective and efficient communication, which relates to the source availability facet of the FES.

Furthermore, various studies show the relation between one or more individual facets of NWW and those of the feedback environment and/or LMX quality. In particular, numerous studies on flexible work designs and teleworking touch upon the relation between these facets of NWW and the feedback environment and/or LMX quality. Most underscore the negative effects of such work designs on the FES facet frequency of receiving feedback (e.g., Boell et al., 2016; O’Neill et al., 2009; Sardeshmukh et al., 2012; Thatcher and Zhu, 2006) or on the LMX quality (e.g., Cooper and Kurland, 2002; Golden and Fromen, 2011). An exception is the study of Caillier (2013), who does not find a significant relation between telecommuting and the frequency of receiving feedback. Golden and Fromen (2011) add important nuances to the predominantly negative relations found between teleworking vis-à-vis feedback and LMX. They 
find that the effects of teleworking on the amount of feedback subordinates receive depend on the match between leaders' and subordinates' work modes: if both the leader and the subordinate telework, the latter will receive more feedback compared to teleworking subordinates whose leaders work in a traditional mode. In addition, subordinates working in a traditional mode report more feedback when their leaders also work in a traditional mode, compared to those with leaders who telework.

With regard to the fourth facet of NWW, flexibility in working relations, Branine (2003) finds that job sharers ${ }^{2}$ note the transfer of expertise and knowledge as an advantage of their flexible arrangement, as well as the mutual support they receive from each other, which relates to the source credibility facet of the FES. Similarly, Kossek and Lee (2008) argue that reduced-load work (i.e., a specific form of part-time work) improves co-worker relationships and communication.

The fifth facet of NWW, a freely accessible open workplace, is, as mentioned earlier, intended to minimize physical and mental distance in the work place by stimulating encounters and cooperation among colleagues. According to the social relations approach, this minimized distance should enhance feedback (Oldham and Brass, 1979). However, from a sociotechnical perspective, the open workspace is expected to hamper feedback, due to the reduced privacy (Oldham and Brass, 1979). The few empirical studies that explicitly analyze the effect of open workplaces on feedback find mixed results. Oldham and Brass (1979) find that open workplaces negatively affect the frequency of supervisor feedback; however, they find no effect on the frequency of co-worker feedback. Pejtersen et al. (2006) find no effect of open workplaces on the frequency of receiving feedback. Bodin Danielsson et al. (2013) find that workers in mediumsized open-plan offices (i.e., 10-24 people in a room with individual workstations) report

2. Job sharing refers to a flexible working relation in which two workers are responsible for one full-time position. 
significantly higher leadership quality compared to workers who have their own single-room office and the authors argue this can increase LMX quality. Conversely, they find that workers in flex offices (i.e., open-plan offices without individual workstations, supplemented with rooms for individual work and telephone calls) report lower leadership quality compared to workers in single-room offices.

Based on the above literature, we expect the frequency with which employees receive feedback to mediate the relation between NWW facets and informal learning, without a priori formulating expectations regarding the sign of the effect.

H2: $\quad$ The frequency of receiving feedback mediates the relation between NWW and informal learning.

Figure 1 gives an overview of the hypothesized relation between NWW facets and informal learning.

Insert Figure 1 about here

\section{Data and methodology}

Our data stem from a survey among a panel of Dutch households collected by $\mathrm{RMI}^{3}$. The survey was a follow-up to the survey in June 2013 used to gather the data on NWW used in Gerards et al. (2018). In April 2015, the questionnaire was sent to the 1,007 respondents (including those who partially responded) to the earlier survey. This resulted in 762 responses. To focus on employees only, we excluded 45 entrepreneurs. Further, we excluded 75 respondents

3. See http://www.rminteractive.nl/panels/. 
who stated not working in a building (e.g., truck, taxi, and train drivers, delivery workers), because the fifth NWW facet regarding a freely accessible open workplace does not refer to these workers. ${ }^{4}$ This resulted in an estimation sample of 642 employees from a broad variety of occupational fields and sectors.

To measure informal learning, we use the three-statement version of the Programme for the International Assessment of Adult Competencies (PIAAC) survey (Organisation for Economic Co-operation and Development, or OECD, 2014). The respondents were asked to rate the three statements on a five-point scale, ranging from "never" to "every day." An example item is "In your job, how often do you learn new work-related things from co-workers or supervisors?" All items are listed in Appendix A $(\alpha=0.80)$.

To measure the extent to which employees are affected by NWW, we use the 10 items from Gerards et al. (2018) that together cover the five NWW facets. ${ }^{5}$ All items on this scale are rated on a five-point scale ranging from "not at all" to "to a very high degree." An overview of all items used to measure NWW is presented in Appendix A $(\alpha=0.81)$.

Building on various studies (e.g., Morran and Stockton, 1980; Nelen and De Grip, 2009; Steelman et al., 2004), we construct our measure for the frequency of receiving feedback from four items, distinguishing between positive and critical feedback. These items, derived from Nelen and De Grip (2009) and Steelman et al. (2004), measure the frequency with which respondents receive positive and/or critical feedback from their co-workers and supervisors on a

4. Gerards et al. (2018) also exclude these workers.

5. The items to measure time- and location-independent work (facet 1) and management on output (facet 2) originate from the Maastricht Autonomy Questionnaire (De Jonge, Landeweerd, and Van Breukelen, 1994). The items to measure access to organizational knowledge (facet 3 ) and flexibility in working relations (facet 4) were developed by the authors to match the definitions of these facets of Baane et al. (2010). The items to measure a freely accessible open workplace (facet 5) were developed by Gerards et al. (2018) to match the facet description of Halford (2005) and Graham (2004). 
seven-point scale ranging from "never" to "always". The items are listed in Appendix A ( $\alpha=$ $0.80)$.

We measure our control variables as follows: the Big Five by using the 15-item short Big Five Inventory ( $\alpha=0.68$ for neuroticism, $\alpha=0.67$ for extraversion, $\alpha=0.61$ for conscientiousness, $\alpha=0.55$ for openness, $\alpha=0.48$ for agreeableness; see, e.g., Gerlitz and Schupp, 2005; Lang et al., 2011), optimism by using the Life Orientation Test - Revised (LOT$\mathrm{R} ; \alpha=0.78$; see Scheier et al., 1994), and work motivation by using the items on extrinsic social motivation $(\alpha=0.79)$, extrinsic material motivation $(\alpha=0.78)$, and intrinsic motivation $(\alpha=$ 0.89) of the Multidimensional Work Motivation Scale (Gagné et al., 2015). All the variables discussed thus far were constructed using regression scoring to obtain the weighted sum of the underlying items and standardized to a mean of zero and a standard deviation of one.

Furthermore, we include a measure for organizational learning support, consisting of nine $0=$ no $/ 1=$ yes items on whether several human resource instruments were used for the respondent. These instruments include, among others, training, job rotation, performance appraisal, a personal development plan, and coaching. These nine items were summed and subsequently standardized to a mean of zero and a standard deviation of one. Moreover, we control for recent formal training participation (having participated in training in the 12 months preceding the survey or participating at the time of the survey), the percentage of time respondents work in a team, their job tenure, age, and educational attainment (each in five categories), 14 sectors of industry, and 12 occupational fields.

Table 1 shows both the Cronbach alpha coefficient for the various facets of NWW and the correlations between NWW (both the aggregate variable and the separate facets of NWW), informal learning, and the frequency of receiving feedback. All facets of NWW, except management on output, appear to be significantly correlated to informal learning, whereby access 
to organizational knowledge shows the strongest correlation to informal learning. Furthermore, the frequency of receiving feedback is significantly correlated with informal learning, NWW as an aggregate variable, and all individual facets of NWW. Finally, we observe that time- and location-independent work and access to organizational knowledge show the strongest correlation with NWW as an aggregate construct, followed by the facet flexibility in working relations and, at some distance, management on output and a freely accessible open workplace. All Cronbach alphas show that the variables we distinguish are internally consistent. ${ }^{6}$ Moreover, we perform factor analysis based on a polychoric correlation matrix ${ }^{7}$ on the latent constructs of informal learning, feedback, and the multi-itemed NWW facets time- and location-independent work, access to organizational knowledge, and a freely accessible open workplace which all show only one item has an eigenvalue above one and all have adequate to strong factor loadings. ${ }^{8}$

Insert Table 1 about here

\section{Results}

\subsection{Main results}

We first test a mediation model with the aggregate NWW variable as the independent variable. We apply the Preacher-Hayes (2008) bootstrap method for mediation analysis to overcome the major limitation of the causal steps approach introduced by Baron and Kenny (1986), that the

6. The second facet (management on output) and fourth facet (flexibility in working relations) are single-item facets. Applying the criteria developed by Fuchs and Diamantopoulos (2009), Gerards et al. (2018) conclude that using a single item for these facets is justifiable, since both facets are relatively concrete and unidimensional and the sampled population is very diverse, including 12 different occupational fields across all sectors of industry.

7. When ordinal data are used, factor analysis based on a polychoric correlation matrix is preferred over standard factor analysis based on Pearson correlations (Holgado-Tello et al., 2010).

8. Across all these factor analyses, the lowest factor loading we observe is 0.54 and the highest is 0.87 . The results are available from the authors upon request. 
existence of indirect effects is inferred and not tested (Hayes, 2009). The Preacher-Hayes bootstrap method enables us to test the specific indirect effects $\left(\mathrm{a}_{\mathrm{i}} \mathrm{b}_{\mathrm{i}}\right)$, the total indirect effect $(\Sigma$ $\left(\mathrm{a}_{\mathrm{i}} \mathrm{b}_{\mathrm{i}}\right)$ ), and the total effect (c). It uses ordinary least squares regressions to estimate the coefficients of all direct relations $\left(\mathrm{a}_{\mathrm{i}}, \mathrm{b}_{\mathrm{i}}\right.$, and $\left.\mathrm{c}^{\prime}\right)$, followed by bootstrapping to compute the confidence intervals that determine the significance of the indirect and total effects.

Figure 2 summarizes our findings with respect to NWW as an aggregate construct. The figure shows that NWW have a significant positive total effect on informal learning $(\beta=0.15)$. Moreover, NWW are significantly positively related to the mediator feedback frequency $(\beta=$ 0.26). In turn, the frequency of receiving feedback is highly significant positively related to informal learning $(\beta=0.21)$. When taking account of the indirect mediating effect of the frequency of receiving feedback ( $\beta=0.06$ ), there remains a positive and highly significant direct effect of NWW on informal learning $(\beta=0.09) .{ }^{9}$ Hence, there is partial mediation, although the direct effect $(\beta=0.09)$ is larger than the indirect effect $(\beta=0.06)$.

Of our control variables, intrinsic work motivation, recent formal training participation, the percentage of time performing teamwork, and organizational learning support are all significantly positively related to informal learning. Moreover, those with a master degree report significantly more informal learning compared to those with lower levels of education. Furthermore, we observe a significant negative relation between the Big 5 personality trait conscientiousness and informal learning. ${ }^{10}$ Finally, we find no significant effects from our control variables age, job tenure, neuroticism, extraversion, openness to experience, agreeableness, optimism, extrinsic

9. Appendix B presents the bootstrap results we use to determine the significance of the indirect effect. It shows the coefficients of the indirect effect as well as the bootstrapped standard errors, $\mathrm{z}$-values, and confidence intervals. Since zero is not included in the confidence intervals, the indirect effect is significant. We round the numbers in the main text and figures to two decimals.

10. Noe et al. (2013) did not find any of the Big Five personality dimensions to be significantly related to informal learning. 
work motivation, sector, and occupation. Our total model is highly significant $(p<0.001)$ and explains 41 percent of the variance in informal learning.

Insert Figure 2 about here

Second, we test a mediation model that includes the five separate facets of NWW as independent variables, again using the Preacher-Hayes (2008) bootstrap method and the same controls as before. Figure 3 summarizes the findings of this analysis. The NWW facet access to organizational knowledge is the only facet with a significant total effect $(\beta=0.13)$ on informal learning. These results provide only partial support for $\mathrm{H} 1$, which predicts a positive relation for all five facets. However, we see significant relations between the facets access to organizational knowledge, flexibility in working relations, and a freely accessible open workplace and the mediator feedback frequency $(\beta=0.11, \beta=0.13$, and $\beta=0.11$, respectively). Further, the mediating variable feedback frequency is highly significantly $(\beta=0.21)$ related to informal learning.

The specific indirect effects of the five facets of NWW on informal learning that run via the mediator are shown in parentheses and the direct effects after accounting for mediation are shown in brackets in Figure 3. When taking account of the mediation, the direct effect of access to organizational knowledge $(\beta=0.11)$ on informal learning hardly drops, as in shown by the magnitude of the coefficient, and remains highly significant. Hence, this effect is mediated by the frequency of receiving feedback only to a very limited extent. The other significant indirect effects on informal learning are from the facets flexibility in working relations $(\beta=0.03)$ and a freely accessible open workplace $(\beta=0.02) .{ }^{11}$ These results only partly support $\mathrm{H} 2$, which predicts a mediating role for feedback between all NWW facets and informal learning. The total

11. See Appendix $\mathrm{C}$ for the corresponding bootstrap results. 
model is again highly significant $(p<0.001)$ and explains 42 percent of the variance in informal learning. The effects of our control variables are the same as found for our first model with NWW as an aggregate variable.

The effect size of access to organizational knowledge $(\beta=0.11)$ is not as large as the effect size of the frequency of receiving feedback $(\beta=0.21)$ and is smaller than the effect of the control variable intrinsic work motivation $(\beta=0.24)$ but similar in magnitude to several of the other known antecedents of informal learning that turned out to be significant, such as recent formal training participation $(\beta=0.14)$, the percentage of time performing teamwork $(\beta=0.12)$, and organizational learning support $(\beta=0.09)$.

Insert Figure 3 about here

\subsection{Additional analysis using a narrower measure of informal learning}

In our main analysis, we measured informal learning by the three-statement version of the PIAAC survey (OECD, 2014). However, two of the items- "How often does your job involve learning-by-doing from the tasks you perform?" and "How often does your job involve keeping up-to-date with new products and services?"- do not relate as logically to our mediating variable feedback as the third item- "In your job, how often do you learn new work-related things from co-workers or supervisors?" Therefore, we might expect that the mediating role of the frequency of receiving feedback would increase in magnitude when we use a narrower measure of informal learning, based on the third item only. 
Figure 4 shows the results when we use this narrower measure of informal learning. ${ }^{12}$ As expected, the figure shows a slightly stronger relation between the frequency of receiving feedback and informal learning from colleagues and supervisors $(\beta=0.23)$, compared to $\beta=0.21$ in Figure 3 when using the broader definition of informal learning. Concomitantly, the total indirect effect also increases slightly, from 0.08 (see Figure 3) to 0.09. More interestingly, apart from the positive effect of the facet access to organizational knowledge $(\beta=0.15)$, we now find two more facets of NWW that directly affect informal learning from colleagues and supervisors: Management on output negatively relates to informal learning from colleagues and supervisors $(\beta$ $=-0.11)$, whereas flexibility in working relations positively relates to informal learning $(\beta=$ 0.09), although this latter relation is only weakly significant. However, when accounting for the mediating effect of the frequency of receiving feedback, only management on output $(\beta=-0.10)$ and access to organizational knowledge $(\beta=0.13)$ remain significantly directly related to informal learning from colleagues and supervisors. Their coefficients have hardly decreased. The total model is again highly significant $(p<0.001)$ but explains only 33 percent of the variance in informal learning from colleagues and supervisors, compared to the 42 percent variance explained by the main model, shown in Figure 3.

Insert Figure 4 about here

\subsection{Additional analysis distinguishing positive and critical feedback as separate mediators}

Following, for instance, Morran and Stockton (1980), Nelen and De Grip (2009), and Steelman et al. (2004), we perform an additional analysis, distinguishing positive and critical feedback as separate mediators. Although confirmatory factor analyses based on a polychoric correlation matrix and Cronbach's alpha suggest that the four items we use to measure feedback form one

12. See Appendix D for the corresponding bootstrap results. 
construct, ${ }^{13}$ separate constructs for positive and critical feedback also result in good factor loadings and Cronbach alphas. ${ }^{14}$

Figure 5 shows the results of this additional analysis, again using the Preacher-Hayes (2008) bootstrap method for multiple mediation and control variables and using the same controls as before. ${ }^{15}$ As in our main model, the NWW facet access to organizational knowledge is the only facet with a significant total effect $(\beta=0.13)$ on informal learning and this effect hardly decreases when accounting for mediation $(\beta=0.11)$. However, we can now see significant relations between access to organizational knowledge and flexibility in working relations and the mediators positive feedback ( $\beta=0.12$ and $\beta=0.13$, respectively) and critical feedback $(\beta=0.08$ and $\beta=0.09$, respectively). Furthermore, the facet management on output $(\beta=-0.10)$ has a significant negative relation with the mediator critical feedback and the facet freely accessible open workplace $(\beta=0.13)$ has a significant positive relation with the mediator positive feedback. Finally, positive feedback $(\beta=0.08)$ and critical feedback $(\beta=0.16)$ are significantly related to informal learning, although the former relation is only weakly significant.

However, whereas the facets access to organizational knowledge, flexibility in working relations, and a freely accessible open workplace showed significant indirect effects on informal learning in our main model, we see here only indirect effects for the facets management on output $(\beta=-0.02)$ and flexibility in working relations $(\beta=0.01)$, both of which run via critical feedback and are only weakly significant. The total model is again highly significant $(p<0.001)$ and

13. Only one eigenvalue is above one, there are strong factor loadings (between 0.72 and 0.78 ) on only one factor, and the Cronbach alpha is 0.80 .

14. Only one eigenvalue is above one and there are factor loadings of 0.79 and a Cronbach alpha of 0.81 for positive feedback; only one eigenvalue is above one and there are factor loadings of 0.74 and a Cronbach alpha of 0.76 for critical feedback.

15. See Appendix E for the corresponding bootstrap results. 
explains 42 percent of the variance in informal learning. The effects of our control variables are the same as found in our previous models. ${ }^{16}$

Insert Figure 5 about here

\section{Discussion}

Controlling for a wide range of known antecedents of informal learning, we find that NWW, as an aggregate construct, are positively related to the informal learning of employees in the Netherlands. This relation is partially mediated by the frequency with which employees receive feedback. However, the direct effect of NWW on informal learning is larger than the indirect effect. Our subsequent analysis, which focuses on the five separate facets of NWW, reveals that access to organizational knowledge is the only NWW facet that positively affects informal learning. This effect is only marginally mediated by the frequency of receiving feedback. The facets time- and location-independent work, management on output, flexibility in working relations, and a freely accessible open workplace are not significantly related to informal learning. The only significant indirect effects on informal learning via the frequency of receiving feedback are from the facets access to organizational knowledge, flexibility in working relations, and a freely accessible open workplace.

Additional analysis using a narrower measure of informal learning shows that the facet management on output relates negatively and the facet access to organizational knowledge relates positively to informal learning from colleagues and supervisors when the mediating effect of the frequency of receiving feedback is included.

16. We also estimated a model with both the narrow definition of informal learning from colleagues and supervisors as a dependent variable and distinguishing between positive and critical feedback. However, the results did not provide any additional insight. The results are available from the authors upon request. 
Additional analysis also shows that critical feedback is much more strongly related to informal learning, compared to positive feedback. Following this, the mediating effect of the frequency of receiving feedback on informal learning mostly runs via critical feedback and less so via positive feedback.

\section{1 Theoretical contributions}

Our study contributes to the literature on NWW and the literature on (the antecedents of) informal learning in the workplace by showing that NWW, as an aggregate construct, will increase informal learning at work, whereby access to organizational knowledge appears to be an independent driver of informal learning in the broad sense, and that management on output appears to restrict informal learning from colleagues and supervisors. The effect sizes we find for access to organizational knowledge on informal learning and management on output for informal learning from colleagues and supervisors are similar to those we find for several other antecedents of informal learning, such as recent formal training participation, percentage of time performing teamwork, and organizational learning support. In addition, we show that the frequency with which employees receive feedback partially mediates the effect of NWW on informal learning to a small extent. This mediating effect mostly runs via critical feedback and less so via positive feedback.

Similarly, we also extend the emerging literature on the effects of NWW on employee outcomes such as work engagement (Gerards et al., 2018; Ten Brummelhuis et al., 2012), employee performance (De Leede and Kraijenbrink, 2014), work-related flow (Peters et al., 2014), and productivity and organizational commitment (De Leede and Heuver, 2017), by showing that NWW, as an aggregate concept, are positively related to informal learning. Our findings that access to organizational knowledge is the only facet that directly affects informal 
learning and that the indirect effects that run via positive and critical feedback are relatively small suggest that the effect of NWW on informal learning is largely a direct process, without intervening mechanisms.

Moreover, several of our findings are relevant to the teleworking literature. The negative relation we observe for the NWW facet management on output-which is a key component of what is also known in the literature as teleworking — and critical feedback is in line with most of the empirical evidence which also points toward this negative relation (e.g., Boell et al., 2016; O'Neill et al., 2009; Sardeshmukh et al., 2012; Thatcher and Zhu, 2006). The absence of any significant relation of the NWW facet time- and location-independent work-another key component of what is known as teleworking — with feedback lends support to the recent empirical evidence of Caillier (2013), who finds no effect of teleworking on receiving feedback at work. However, the positive relation we find between the NWW facet access to organizational knowledge—also a key component of teleworking—and feedback differs from the aforementioned empirical studies.

In addition, the significant relations we observe between, on the one hand, the four NWW facets management on output, access to organizational knowledge, flexibility in working relations, and a freely accessible open workplace and, other the other hand, the FES facets frequencies of receiving positive and critical feedback contribute to the literature on the feedback environment — where the antecedents of the feedback environment are understudied (Dahling et al., 2017) - with empirical evidence on new antecedents of two important facets of the feedback environment, namely, the frequency of positive feedback and the frequency of critical feedback (Steelman et al., 2004).

Lastly, the positive effect of the NWW facet access to organizational knowledge on informal learning, which we predicted based on the JD-R model, and the negative effect of 
management on output on informal learning from colleagues and supervisors add several pieces to the thus far inconclusive evidence on the effects of teleworking on informal learning. For instance, Cooper and Kurland (2002) and Kurland and Bailey (1999) find a negative relation between teleworking and informal learning, whereas De Leede and Kraijenbrink (2014) find a positive relation, and Boell et al. (2016) conclude that empirical findings concerning telework are often paradoxical. However, by analyzing the individual components of NWW (and, with those, teleworking) as well as two different measures of informal learning, we find there are both positive (access to organizational knowledge) and negative (management on output) effects of certain NWW facets on informal learning (from colleagues and supervisors). This shows that what would have seemed paradoxical based on analyses using aggregate measures of NWW and informal learning can be logically explained by looking at more specific components of teleworking and informal learning.

\section{2 Practical implications}

Rarely, if ever, is the promotion of informal learning regarded as one of the reasons why organizations advocate or implement NWW. Although we find that NWW, as an aggregate construct, will increase informal learning at work, our findings also show that not all NWW facets increase informal learning. Whereas introducing access to organizational knowledge appears to be a driver of informal learning, management on output seems to decrease informal learning specifically from colleagues and supervisors. These findings are of interest for human resource and general managers seeking new ways to stimulate informal learning. Since information and communication technologies offer ample opportunities for giving employees access to organizational knowledge, organizations should take these opportunities to foster informal learning at work. However, when management on output is the current practice, 
organizations should remain alert, since, when the output itself is apparently paramount, opportunities for informal learning from colleagues and supervisors as well as the frequency of critical feedback could be reduced by this management style.

\subsection{Limitations and future research}

Our use of cross-sectional data does not allow us to identify causal relations. Moreover, cultural differences between working populations in different countries may restrict the external validity of our findings, which are derived from a data set of the Dutch working population. Future research should therefore attempt to analyze the effects of NWW in a longitudinal and international setting, considering different cultural dimensions. This could also allow the distinction between employees already used to working with particular NWW facets since several years and those who just started to work with them. Future research in the field of NWW should also aim to obtain more insight into the extent to which informal learning mediates the positive effects of NWW on employee performance, work engagement, work-related flow, productivity, and organizational commitment, as found in other studies on NWW. 


\section{References}

Allen, T. D., Golden, T. D. and Shockley, K. M. (2015). How effective is telecommuting? Assessing the status of our scientific findings. Psychological Science in the Public Interest, 16(2), 40-68.

Anseel, F., Beatty, A. S., Shen, W., Lievens, F. and Sackett, P. R. (2015). How are we doing after 30 years? A meta-analytic review of the antecedents and outcomes of feedbackseeking behavior. Journal of Management, 41(1), 318-348.

Baane, R., Houtkamp, P. and Knotter, M. (2010). Het Nieuwe Werken ontrafeld-Over Bricks, Bytes en Behavior. Koninklijke Van Gorcum. Assen.

Bakker, A. B. and Demerouti, E. (2007). The job demands-resources model: State of the art. Journal of Managerial Psychology, 22(3), 309-328.

Baron, R. M. and Kenny, D.A. (1986). The moderator-mediator variable distinction in social psychological research: Conceptual, strategic, and statistical considerations. Journal of Personality and Social Psychology, 51(6), 1173.

Bear, D. J., Tompson, H. B., Morrison, C. L., Vickers, M., Paradise, A., Czarnowsky, M., et al. (2008). Tapping the potential of informal learning. An ASTD research study, Alexandria, VA: American Society for Training and Development. Alexandria, VA: American Society for Training and Development.

Blok, M. M., Groenesteijn, L., Schelvis, R. and Vink, P. (2012). New ways of working: does flexibility in time and location of work change work behavior and affect business outcomes? Work, 41 (Supplement 1), 2605-2610.

Bodin Danielsson, C., Wulff, C. and Westerlund, H. (2013). Is perception of leadership 
influenced by office environment?. Journal of Corporate Real Estate, 15(3/4), 194-212.

Boell, S. K., Cecez-Kecmanovic, D. and Campbell, J. (2016), Telework paradoxes and practices: the importance of the nature of work. New Technology, Work and Employment, 31: 114131.

Branine, M. (2003). Part-time work and jobsharing in health care: is the NHS a family-friendly employer?. Journal of Health Organization and Management, 17(1), 53-68.

Caillier, J. G. (2013). Does teleworking affect managing for results and constructive feedback? A research note. Canadian Public Administration, 56(4), 638-654.

Cerasoli, C. P., Alliger, G. M., Donsbach, J. S., Mathieu, J. E., Tannenbaum, S. I. and Orvis, K.A. (2017). Antecedents and Outcomes of Informal Learning Behaviors: a MetaAnalysis. Journal of Business and Psychology, 1-28.

Cooper, C. D. and Kurland, N. B. (2002). Telecommuting, professional isolation, and employee development in public and private organizations. Journal of Organizational Behavior, 23(4), 511-532.

Dahling, J.J., Gabriel, A.S. and MacGowan, R. (2017). Understanding typologies of feedback environment perceptions: A latent profile investigation, Journal of Vocational Behavior, 101, 133-148.

De Grip, A. (2015). The importance of informal learning at work, IZA World of Labor, 162 doi: 10.15185/izawol.162.

De Grip, A., Sauermann, J. and Sieben, I. (2016). The Role of Peers in Estimating TenurePerformance Profiles: Evidence from Personnel Data, Journal of Economic Behavior \& Organization, 126, 39-54.

De Leede, J. and Heuver, P. (2017). New Ways of Working and Leadership: An Empirical Study in the Service Industry. In: New Ways of Working Practices: Antecedents and 
Outcomes (pp. 49-71). Emerald Group Publishing Limited.

De Leede, J. and Kraijenbrink, J. (2014), The Mediating Role of Trust and Social Cohesion in the Effects of New Ways of Working: A Dutch Case Study. In: Human resource management, social innovation and technology (Advanced Series in Management, 14, pp. 3-20). Emerald Group Publishing Limited.

Leede, J., Looise, J. K. and Riemsdijk, M. (2004). Collectivism versus individualism in Dutch employment relations. Human Resource Management Journal, 14(1), 25-39.

De Jonge, J., Landeweerd, J. A. and G. J. P. Van Breukelen (1994). De Maastrichtse autonomielijst: achtergrond, constructie en validering [The Maastricht autonomy questionnaire: background, construction and validation]. Gedrag en Organisatie, 7(1), 27-41.

Ellinger, A. D. (2005). Contextual factors influencing informal learning in a workplace setting: The case of 'Reinventing Itself Company'. Human Resource Development Quarterly, 16, 389-413.

Else Ouweneel, A. P., Taris, T. W., van Zolingen, S. J. and Schreurs, P. J. (2009). How task characteristics and social support relate to managerial learning: Empirical evidence from Dutch home care. The Journal of Psychology, 143(1), 28-44.

Eraut, M. (2004). Informal learning in the workplace. Studies in Continuing Education, 26:2, 247-273.

Fonner, K. L. and Roloff, M. E. (2010). Why teleworkers are more satisfied with their jobs than are office-based workers: When less contact is beneficial. Journal of Applied Communication Research, 38(4), 336-361.

Fuchs, C. and Diamantopoulos, A. (2009). Using single-item measures for construct measurement in management research: Conceptual issues and application guidelines. Die 
Betriebswirtschaft, 69(2), 195.

Gagné, M., Forest, J., Vansteenkiste, M., Crevier-Braud, L., Van den Broeck, A., Aspeli, A.K., (2015). The Multidimensional Work Motivation Scale: Validation evidence in seven languages and nine countries. European Journal of Work and Organizational Psychology, 24(2), 178-196.

Gerards, R., De Grip, A. and Baudewijns, C. (2018). Do New Ways of Working increase work engagement? Personnel Review,47(2), 517-534.

Gerstner, C. R. and Day, D. V. (1997). Meta-Analytic review of leader-member exchange theory: Correlates and construct issues. Journal of Applied Psychology, 82(6), 827.

Gerlitz, J. Y. and Schupp, J. (2005). Zur Erhebung der Big-Five-basierten Persoenlichkeitsmerkmale im SOEP. DIW Research Notes, 4, 2005.

Giffin, K. (1967). The contribution of studies of source credibility to a theory of interpersonal trust in the communication process. Psychological Bulletin, 68(2), 104.

Gijbels, D., Raemdonck, I., Vervecken, D. and Van Herck, J. (2012). Understanding workrelated learning: the case of ICT workers. Journal of Workplace Learning, 24(6), 416429.

Golden, T. D. and Fromen, A. (2011). Does it matter where your manager works? Comparing managerial work mode (traditional, telework, virtual) across subordinate work experiences and outcomes. Human Relations, 64(11), 1451-1475.

Graen, G. B. and Uhl-Bien, M. (1995). Relationship-based approach to leadership: Development of leader-member exchange (LMX) theory of leadership over 25 years: Applying a multilevel multi-domain perspective. The Leadership Quarterly, 6(2), 219-247.

Graham, S. (2004). Beyond the 'dazzling light': from dreams of transcendence to the 'remediation'of urban life. New Media and Society, 6(1), 16-25. 
Halford, S. (2005). Hybrid workspace: Re-spatialisations of work, organisation and management. New Technology, Work and Employment, 20(1), 19-33.

Holgado-Tello, F. P., Chacón-Moscoso, S., Barbero-García, I. and Vila-Abad, E. (2010). Polychoric versus Pearson correlations in exploratory and confirmatory factor analysis of ordinal variables. Quality \& Quantity, 44(1), 153.

Kossek, E. E. and Lee, M. D. (2008). Implementing a reduced-workload arrangement to retain high talent: A case study. The Psychologist-Manager Journal, 11(1), 49.

Kyndt, E., Dochy, F. and Nijs, H. (2009). Learning conditions for non-formal and informal workplace learning. Journal of Workplace Learning, 2, 369-383.

Kurland, N. B. and Bailey, D. E. (1999). When workers are here, there, and everywhere: A discussion of the advantages and challenges of telework. Organizational Dynamics, 28(2), 53-58.

Lang, F. R., John, D., Lüdtke, O., Schupp, J. and Wagner, G. G. (2011). Short assessment of the Big Five: Robust across survey methods except telephone interviewing. Behavior Research Methods, 43(2), 548-567.

Laursen, K. and Foss, N. J. (2003). New human resource management practices, complementarities and the impact on innovation performance. Cambridge Journal of Economics, 27(2), 243-263.

Laursen, K. and Mahnke, V. (2001). Knowledge strategies, firm types, and complementarity in human-resource practices. Journal of Management and Governance, 5(1), 1-27.

London, M. (1995). Giving feedback: Source-centered antecedents and consequences of constructive and destructive feedback. Human Resource Management Review, 5(3), 159188.

Marsick, V. J. and Watkins, K. E. (2001). Informal and incidental learning. New directions for 
adult and continuing education, 2001(89), 25-34.

Morran, K. and Stockton, R. (1980). Effect of self-concept and group member reception of positive and negative feedback. Journal of Counseling Psychology, 27, 260-267.

Mulder, R. (2013). Exploring feedback incidents, their characteristics and the informal learning activities that emanate from them. European Journal of Training and Development, 37(1), 49-71.

Nelen, A. and De Grip, A. (2009). Why Do Part-time Workers Invest Less in Human Capital than Full-timers? Labour, 23(s1), 61-83.

Noe, R. A., Tews, M. J. and Marand, A. D. (2013). Individual differences and informal learning in the workplace. Journal of Vocational Behavior, 83(3), 327-335.

OECD (2014). Technical Report of the Survey of Adult Skills, Reader's Companion. Paris: OECD Publishing.

Oldham, G. R. and Brass, D. J. (1979). Employee reactions to an open-plan office: A naturally occurring quasi-experiment. Administrative Science Quarterly, 267-284.

O'Neill, T. A., Hambley, L. A., Greidanus, N. S., MacDonnell, R. and Kline, T. J. (2009). Predicting teleworker success: an exploration of personality, motivational, situational, and job characteristics. New Technology, Work and Employment, 24(2), 144-162.

Pejtersen, J., Allermann, L., Kristensen, T. S. and Poulsen, O. M. (2006). Indoor climate, psychosocial work environment and symptoms in open-plan offices. Indoor Air, 16(5), $392-401$.

Peters, P., Kraan, K. and P. van Echtelt (2013). Floreren onder condities van Het Nieuwe Werken: minder burnout, meer toewijding?. Tijdschrift voor Arbeidsvraagstukken, 3, 29, 304-321.

Peters, P., Poutsma, E., Van der Heijden, B. I., Bakker, A. B. and T. D. Bruijn (2014). Enjoying 
New Ways to Work: An HRM-Process Approach to Study Flow. Human Resource Management, 53(2), 271-290.

Preacher, K. J. and A. F. Hayes (2008). Asymptotic and resampling strategies for assessing and comparing indirect effects in multiple mediator models. Behavior Research Methods, 40(3), 879-891.

Sardeshmukh, S. R., Sharma, D. and Golden, T. D. (2012). Impact of telework on exhaustion and job engagement: A job demands and job resources model. New Technology, Work and Employment, 27(3), 193-207.

Scheier, M. F., Carver, C. S. and Bridges, M. W. (1994). Distinguishing optimism from neuroticism (and trait anxiety, self-mastery, and self-esteem): a reevaluation of the Life Orientation Test. Journal of Personality and Social Psychology, 67(6), 1063.

Schürmann, E. and Beausaert, S. (2016). What are drivers for informal learning? European Journal of Training and Development, 40(3), 130-154.

Steelman, L. A., Levy, P. E. and Snell, A. F. (2004). The feedback environment scale: Construct definition, measurement, and validation. Educational and Psychological Measurement, 64(1), 165-184.

Ten Brummelhuis, L. L., Bakker, A. B., Hetland, J. and Keulemans, L. (2012). Do new ways of working foster work engagement? Psicothema, 24(1), 113-120.

Ter Hoeven, C. L. and Van Zoonen, W. (2015). Flexible work designs and employee well-being: examining the effects of resources and demands. New Technology, Work and Employment, 30(3), 237-255.

Tews, M. J., Michel, J. W. and Noe, R. A. (2017). Does fun promote learning? The relationship between fun in the workplace and informal learning. Journal of Vocational Behavior, 98, 46-55. 
Thatcher, S. M. and Zhu, X. (2006). Changing identities in a changing workplace: Identification, identity enactment, self-verification, and telecommuting. Academy of Management Review, 31(4), 1076-1088.

Thompson, C. A. and Prottas, D. J. (2006). Relationships among organizational family support, job autonomy, perceived control, and employee well-being. Journal of Occupational Health Psychology, 11(1), 100-118.

Van Ruysseveldt, J. and Van Dijke, M. (2011). When are workload and workplace learning opportunities related in a curvilinear manner? The moderating role of autonomy, Journal of Vocational Behavior, 79, 470-483.

Wielenga-Meijer, E. G., Taris, T. W., Kompier, M. A. and Wigboldus, D. H. (2010). From task characteristics to learning: A systematic review. Scandinavian Journal of Psychology, 51(5), 363-375. 
Table 1. Internal consistencies and correlations between the variables $(N=642)$

\begin{tabular}{lllllllll}
\hline & 1 & 2 & 3 & 4 & 5 & 6 & 7 & 8 \\
\hline 1. Informal learning & $(0.80)$ & & & & & & \\
2. New Ways of Working (aggregate) & $0.34^{*}(0.81)$ & & & & \\
3. NWW Facet 1: Time- and location independent & & & & & & & \\
$\quad$ work & $0.17^{*}$ & $0.74^{*}$ & $(0.79)$ & & & & \\
4. NWW Facet 2: Management on output & 0.10 & $0.55^{*}$ & $0.49^{*}$ & & & & \\
5. NWW Facet 3: Access to organizational & & & & & & & & \\
$\quad$ knowledge & $0.33^{*}$ & $0.75^{*}$ & $0.23^{*}$ & $0.27^{*}$ & $(0.79)$ & & \\
6. NWW Facet 4: Flexibility in working relations & $0.25^{*}$ & $0.69^{*}$ & $0.61^{*}$ & $0.38^{*}$ & $0.33^{*}$ & & \\
7. NWW Facet 5: Freely accessible open workplace & $0.20^{*}$ & $0.55^{*}$ & $0.15^{*}$ & $0.16^{*}$ & $0.35^{*}$ & $0.21^{*}$ & $(0.85)$ \\
8. Frequency of receiving feedback & $0.45^{*}$ & $0.44^{*}$ & $0.29^{*}$ & $0.18^{*}$ & $0.34^{*}$ & $0.36^{*}$ & $0.28^{*}(0.80)$ \\
\hline
\end{tabular}

Cronbach's alphas on the diagonal

* Significant at $\mathrm{P}<.001$ 
Figure 1. Overview of our hypothesized relationship between NWW and informal learning.

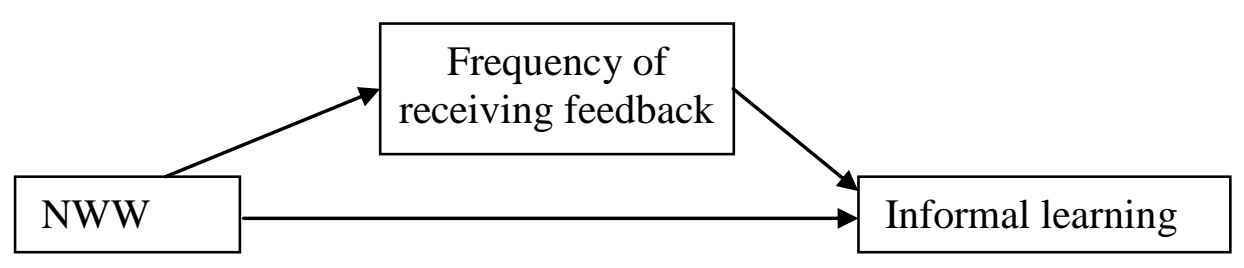

Figure 2. Mediation model of direct and indirect effects of NWW on informal learning.

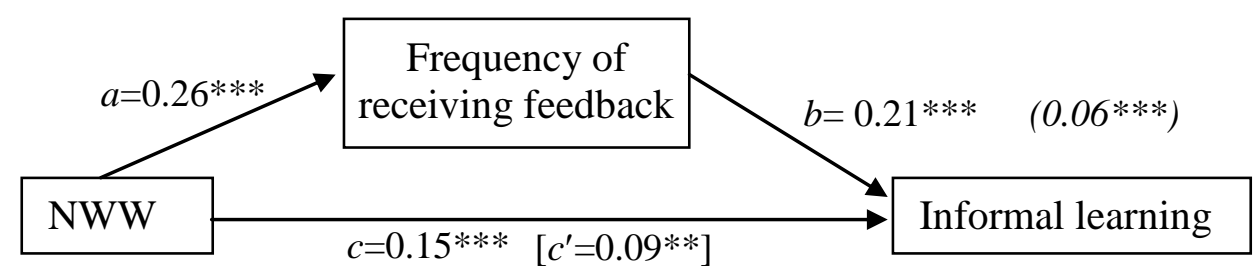

Notes:

- Indirect effect $\left(a^{*} b\right)$ is shown in italics in parentheses. Direct effect of NWW accounting for mediation is shown in brackets.

- $\quad * * * p<0.01, * * p<0.05, * p<0.10$

- $\quad$ Total effect $c=a_{*} b+c^{\prime}$ 
Figure 3. Mediation model of direct and indirect effects of individual facets of NWW on informal learning, via the frequency of receiving feedback.

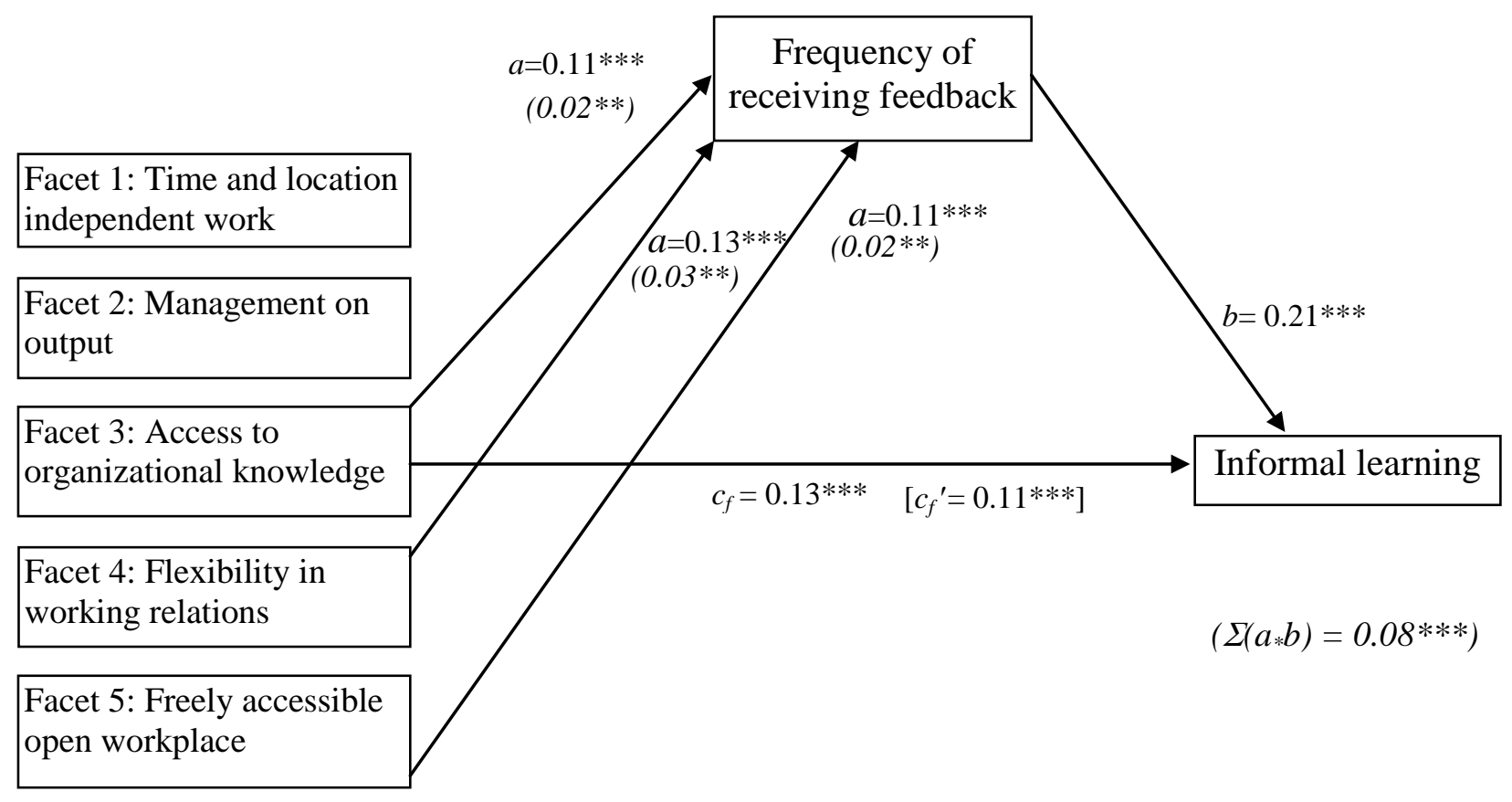

Notes:

- Indirect effects $(a * b)$ and total indirect effect $\left(\Sigma\left(a^{*} b\right)\right)$ are shown in italics in parentheses. Direct effects of NWW facets accounting for mediation are shown in brackets.

- We only show significant relations. $* * * p<0.01, * * p<0.05, * p<0.10$

- Total effect per facet ' $\mathrm{f}$ ' is $c_{\mathrm{f}}=\Sigma\left(a_{\mathrm{f}} \mathrm{*} b\right)+c_{\mathrm{f}}$ ' 
Figure 4. Mediation model of direct and indirect effects of individual facets of NWW on informal learning from colleagues and supervisors, via the frequency of receiving feedback.

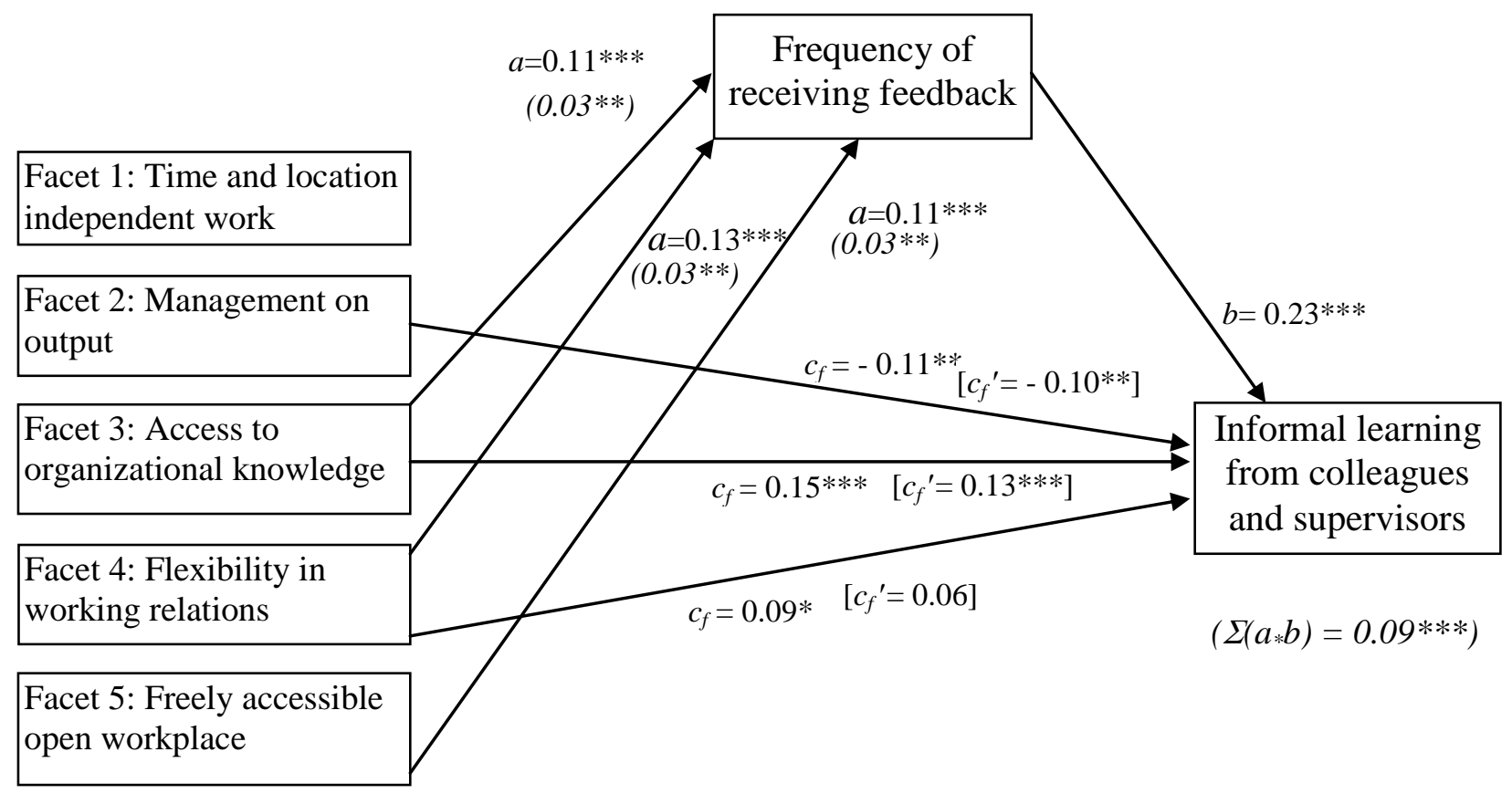

Notes:

- Indirect effects $\left(a_{*} b\right)$ and total indirect effect $\left(\Sigma\left(a^{*} b\right)\right)$ are shown in italics in parentheses. Direct effects of NWW facets accounting for mediation are shown in brackets.

- We only show significant relations. ${ }^{* * *} p<0.01$, ** $p<0.05, * p<0.10$

- Total effect per facet ' $\mathrm{f}$ ' is $c_{\mathrm{f}}=\Sigma\left(a_{, \mathrm{f}^{*}} b\right)+c_{\mathrm{f}}$ ' 
Figure 5. Multiple mediation model of direct and indirect effects of individual facets of NWW on informal learning, via the frequency of receiving positive and critical feedback.

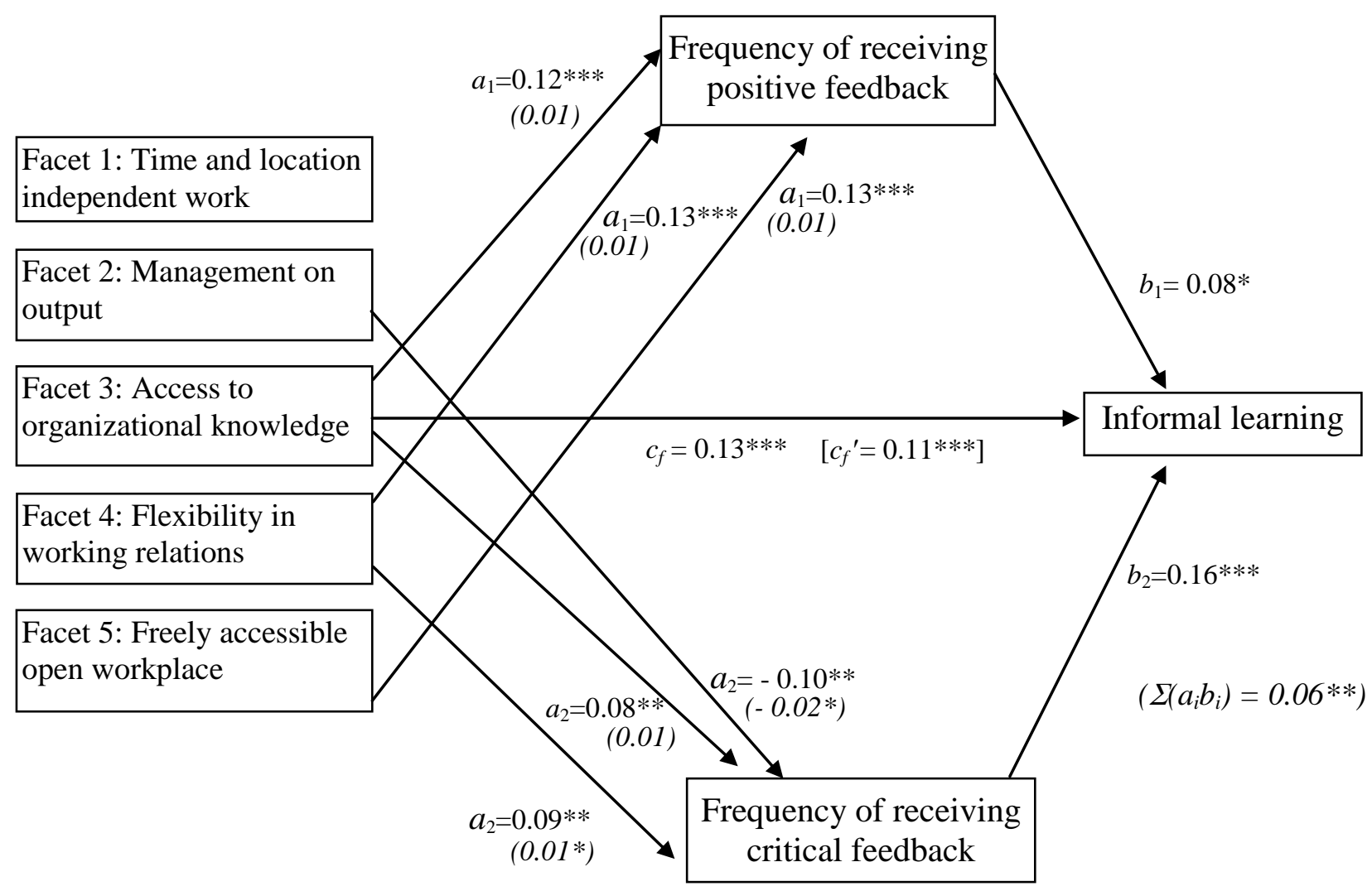

Notes:

- Indirect effects $\left(a_{\mathrm{i}} b_{\mathrm{i}}\right)$ and total indirect effect $\left(\Sigma\left(a_{\mathrm{i}} b_{\mathrm{i}}\right)\right)$ are shown in italics in parentheses. Direct effects of NWW facets accounting for mediation are shown in brackets.

- We only show significant relations. $* * * p<0.01, * * p<0.05, * p<0.10$

- Total effect per facet ' $\mathrm{f}$ ' is $c_{\mathrm{f}}=\Sigma\left(a_{\mathrm{i}, \mathrm{f}}{ }^{*} b_{\mathrm{i}}\right)+c_{\mathrm{f}}$ ' 
Appendix A - Main survey questions

Variabele

Informal Learning

\begin{tabular}{|c|c|c|}
\hline & $\begin{array}{l}\text { In your job, how often do you learn new work- } \\
\text { related things from co-workers or supervisors? }\end{array}$ & (1) never - (5) every day \\
\hline & $\begin{array}{l}\text { How often does your job involve learning-by-doing } \\
\text { from the tasks you perform? }\end{array}$ & (1) never - (5) every day \\
\hline & $\begin{array}{l}\text { How often does your job involve keeping up to date } \\
\text { with new products and services? }\end{array}$ & (1) never - (5) every day \\
\hline \multicolumn{3}{|l|}{ New Ways of Working } \\
\hline \multirow{2}{*}{$\begin{array}{l}\text { Facet 1: Time and location } \\
\text { independent work }\end{array}$} & I am able to set my own working hours & (1) not at all - (5) to a very high degree \\
\hline & I am able to determine where I work & (1) not at all - (5) to a very high degree \\
\hline Facet 2: Management on output & I am able to determine the way I work & (1) not at all - (5) to a very high degree \\
\hline \multirow[t]{4}{*}{$\begin{array}{l}\text { Facet 3: Access to organizational } \\
\text { knowledge }\end{array}$} & $\begin{array}{l}\text { I can access all necessary information on my } \\
\text { computer, smartphone, and/or tablet }\end{array}$ & (1) not at all - (5) to a very high degree \\
\hline & I am able to reach colleagues within the team quickly & (1) not at all - (5) to a very high degree \\
\hline & I am able to reach managers quickly & (1) not at all - (5) to a very high degree \\
\hline & $\begin{array}{l}\text { I am able to reach colleagues outside the team } \\
\text { quickly }\end{array}$ & (1) not at all - (5) to a very high degree \\
\hline $\begin{array}{l}\text { Facet } 4 \text { : Flexibility in working } \\
\text { relations }\end{array}$ & $\begin{array}{l}\text { I have the ability to adapt my working scheme to my } \\
\text { phase of life and ambitions. }\end{array}$ & (1) not at all - (5) to a very high degree \\
\hline \multirow[t]{2}{*}{$\begin{array}{l}\text { Facet } 5 \text { : Freely accessible open } \\
\text { workplace }\end{array}$} & $\begin{array}{l}\text { the building is arranged so that colleagues are easily } \\
\text { accessible }\end{array}$ & (1) not at all - (5) to a very high degree \\
\hline & $\begin{array}{l}\text { The building is arranged so that managers are easily } \\
\text { accessible }\end{array}$ & (1) not at all - (5) to a very high degree \\
\hline \multicolumn{3}{|l|}{$\begin{array}{l}\text { The frequency of receiving } \\
\text { feedback }\end{array}$} \\
\hline \multirow[t]{2}{*}{ Positive feedback } & $\begin{array}{l}\text { How often do your co-workers give you positive } \\
\text { feedback after successfully completing a task? }\end{array}$ & (1) never - (7) always \\
\hline & $\begin{array}{l}\text { How often does your supervisor give you positive } \\
\text { feedback after successfully completing a task? }\end{array}$ & (1) never - (7) always \\
\hline \multirow[t]{2}{*}{ Critical feedback } & $\begin{array}{l}\text { How often do your co-workers tell you how you can } \\
\text { improve your performance? }\end{array}$ & (1) never - (7) always \\
\hline & $\begin{array}{l}\text { How often does your supervisor tell you how you } \\
\text { can improve your performance? }\end{array}$ & (1) never - (7) always \\
\hline
\end{tabular}


Appendix B - Mediation of the effect of NWW on informal learning via the frequency of receiving feedback.

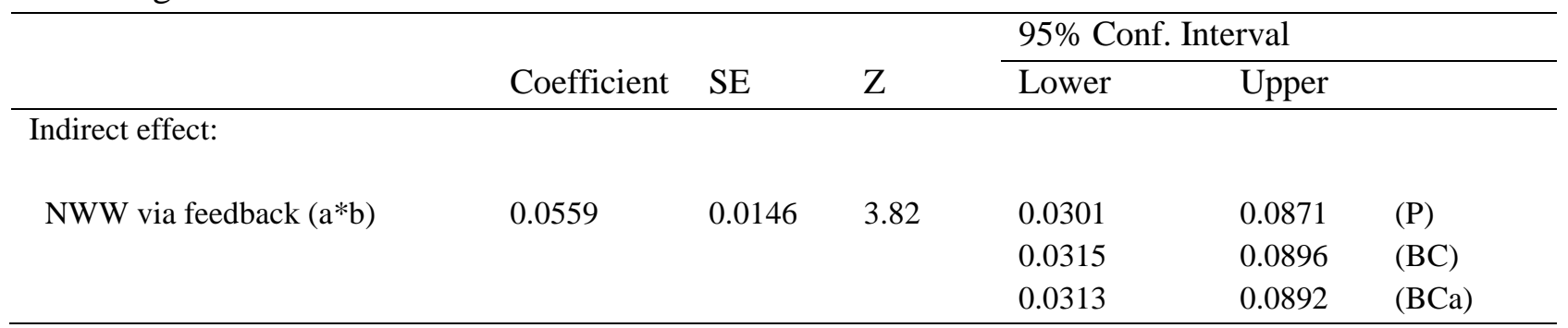

Note: P, percentile; BC, bias corrected; BCa, bias corrected and accelerated; 4,999 bootstrap samples

Appendix $\mathbf{C}$ - Mediation of the effect of the individual NWW facets on informal learning via the frequency of receiving feedback.

\begin{tabular}{|c|c|c|c|c|c|c|}
\hline & \multirow[b]{2}{*}{ Coefficient } & \multirow[b]{2}{*}{ SE } & \multirow[b]{2}{*}{$\mathrm{Z}$} & \multicolumn{3}{|c|}{$95 \%$ Conf. Interval } \\
\hline & & & & Lower & Upper & \\
\hline \multicolumn{7}{|l|}{ Indirect effects: } \\
\hline \multirow[t]{3}{*}{ Facet 1 via feedback $\left(a^{*} b\right)$} & .0116 & .0100 & 1.16 & -0.0069 & 0.0330 & (P) \\
\hline & & & & -0.0050 & 0.0355 & (BC) \\
\hline & & & & -0.0050 & 0.0355 & $(\mathrm{BCa})$ \\
\hline \multirow[t]{3}{*}{ Facet 2 via feedback $(a * b)$} & -.0084 & .0082 & -1.03 & -0.0251 & 0.0066 & (P) \\
\hline & & & & -0.0263 & 0.0057 & (BC) \\
\hline & & & & -0.0263 & 0.0057 & $(\mathrm{BCa})$ \\
\hline \multirow[t]{3}{*}{ Facet 3 via feedback $(a * b)$} & .0238 & .0107 & 2.23 & 0.0056 & 0.0471 & $(\mathrm{P})$ \\
\hline & & & & 0.0061 & 0.0480 & (BC) \\
\hline & & & & 0.0059 & 0.0478 & $(\mathrm{BCa})$ \\
\hline \multirow[t]{3}{*}{ Facet 4 via feedback $(a * b)$} & .0277 & .0111 & 2.50 & 0.0084 & 0.0517 & $(\mathrm{P})$ \\
\hline & & & & 0.0097 & 0.0560 & (BC) \\
\hline & & & & 0.0098 & 0.0560 & (BCa) \\
\hline \multirow[t]{3}{*}{ Facet 5 via feedback $\left(a^{*} b\right)$} & .0239 & .0097 & 2.47 & 0.0071 & 0.0452 & $(\mathrm{P})$ \\
\hline & & & & 0.0081 & 0.0471 & (BC) \\
\hline & & & & 0.0082 & 0.0473 & (BCa) \\
\hline \multirow[t]{3}{*}{ Total indirect } & .0785 & .0218 & 3.61 & 0.0403 & 0.1254 & $(\mathrm{P})$ \\
\hline & & & & 0.0422 & 0.1275 & (BC) \\
\hline & & & & 0.0422 & 0.1272 & $(\mathrm{BCa})$ \\
\hline
\end{tabular}

Note: $\mathrm{P}$, percentile; $\mathrm{BC}$, bias corrected; $\mathrm{BCa}$, bias corrected and accelerated; 4,999 bootstrap samples 
Appendix D - Mediation of the effect of the individual NWW facets on informal learning from colleagues and supervisors, via the frequency of receiving feedback.

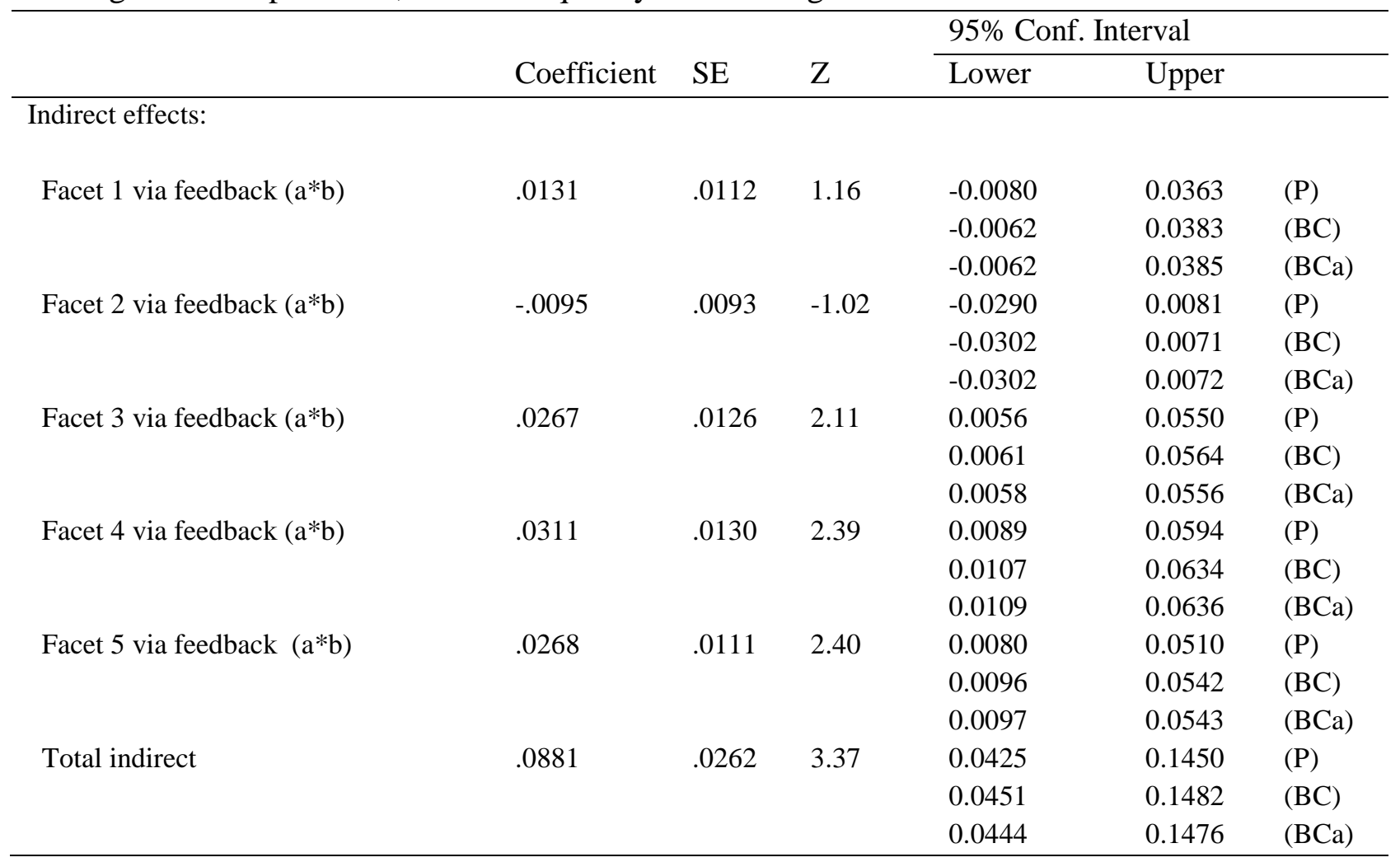

Note: P, percentile; BC, bias corrected; $\mathrm{BCa}$, bias corrected and accelerated; 4,999 bootstrap samples 
Appendix E - Mediation of the effect of the individual NWW facets on informal learning via positive and critical feedback.

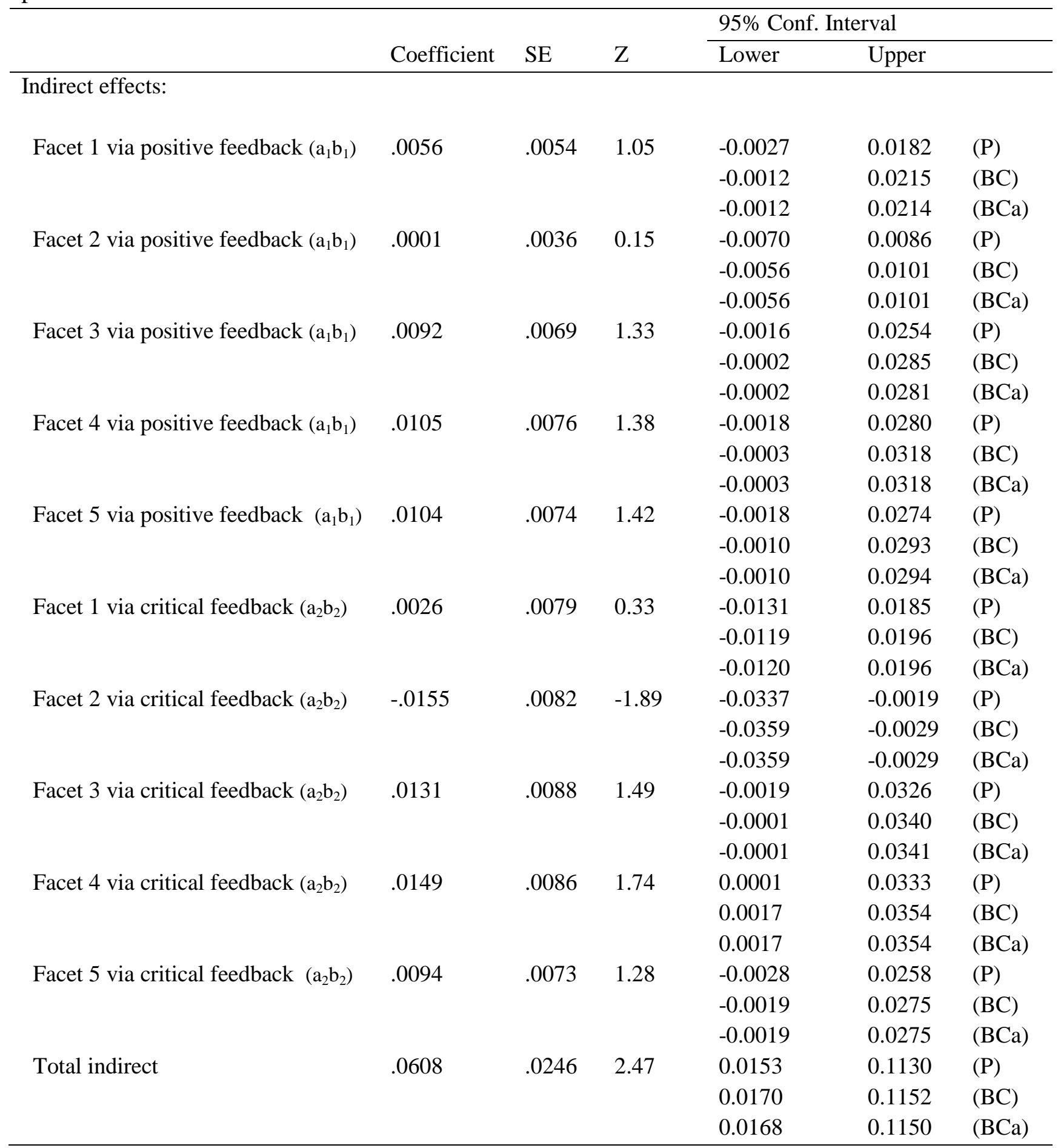

Note: P, percentile; BC, bias corrected; $\mathrm{BCa}$, bias corrected and accelerated; 4,999 bootstrap samples 